\title{
BMJ Global Health Proximate and socio-economic determinants of under-five mortality in Benin, 2017/2018
}

\author{
Sanni Yaya (D) , ${ }^{1,2}$ Bright Opoku Ahinkorah (D) , ${ }^{3}$ Edward Kwabena Ameyaw (D) ,3 \\ Abdul-Aziz Seidu (D) , ${ }^{4}$ Eugene Kofuor Maafo Darteh, ${ }^{5}$ Nicholas Kofi Adjei ${ }^{6}$
}

To cite: Yaya S, Ahinkorah BO, Ameyaw EK, et al. Proximate and socio-economic determinants of underfive mortality in Benin, 2017/2018. BMJ Global Health 2020;5:e002761. doi:10.1136/ bmjgh-2020-002761

Handling editor Seye Abimbola

Received 27 April 2020

Revised 11 July 2020

Accepted 14 July 2020

Check for updates

(c) Author(s) (or their employer(s)) 2020. Re-use permitted under CC BY-NC. No commercial re-use. See rights and permissions. Published by BMJ.

${ }^{1}$ School of International Development and Global Studies, University of Ottawa, Ottawa, Ontario, Canada

${ }^{2}$ The George Institute for Global Health, Imperial College London, London, UK

${ }^{3}$ School of Public Health, Faculty of Health, University of Technology Sydney, Sydney, New South Wales, Australia ${ }^{4}$ College of Public Health, Medical and Veterinary Sciences, James Cook University, Townsville, Queensland, Australia ${ }^{5}$ Department of Population and Health, University of Cape Coast, Cape Coast, Ghana

${ }^{6}$ Leibniz Institute for Prevention Research and Epidemiology, Bremen, Bremen, Germany

Correspondence to

Dr Sanni Yaya;

sanni.yaya@uottawa.ca

\section{ABSTRACT}

Background Globally, under-five mortality has declined significantly, but still remains a critical public health problem in sub-Saharan African countries such as Benin. Yet, there is no empirical information in the country using a nationally representative data to explain this phenomenon. The aim of this study was to examine how proximate and socio-economic factors are associated with mortality in under-five children in Benin.

Methods We analysed data of 5977 under-five children using the 2017 to 2018 Benin Demographic and Health Surveys. Multivariable hierarchical logistic regression modelling technique was applied to investigate the factors associated with under-five mortality. The fit of the models were assessed using variance inflation factor and Pseudo $\mathrm{R}^{2}$. Results were reported as adjusted odds ratios (aORs). All comparisons were considered to be statistically significant at $p<0.05$.

Results The study revealed an under-five mortality rate of 96 deaths per 1000 live births in Benin. Regarding the socio-economic determinants, the risk of death was found to be higher in children born in the Plateau region ( $\mathrm{aOR}=3.05 ; 95 \% \mathrm{Cl}: 1.29$ to 7.64$)$, in rural areas (aOR $=1.45 ; 95 \% \mathrm{Cl}: 1.07$ to 1.98 ) and children with $\geq 4$ birth rank and $>2$ years of birth interval $(\mathrm{aOR}=1.52 ; 95 \%$ $\mathrm{Cl}: 1.07$ to 2.17). Among the proximate determinants, we found the probability of death to be higher in children whose mothers had no postnatal check-up (PNC) visits after delivery (aOR=1.79; 95\% Cl: 1.22 to 2.63), but there was no significant association between individual-level/ household-level factors and under-five mortality.

Conclusion This study has established that socioeconomic and proximate factors are important determinants of under-five mortality in Benin. Our findings have shown the need to implement both socio-economic and proximate interventions, particularly those related to PNC visits when planning on under-five mortality. To achieve this, a comprehensive, long-term public health interventions, which consider the disparity in the access and utilisation of healthcare services in Benin are key.

\section{BACKGROUND}

Ending preventable deaths, including deaths of under-five children is one of the key targets of the Sustainable Development Goal-3

\section{Key questions}

What is already known?

- Death of under-five children remains a critical issue of concern to policymakers, experts in public health and demographers.

- Despite the significant reduction in under-five deaths globally, it remains a critical public health issue in sub-Saharan African countries like Benin.

What are the new findings?

- Compared with children born in urban settings, those born in rural areas have a higher likelihood of dying before the age of 5 years in Benin.

- The likelihood of under-five mortality decreases with postnatal check-up (PNC) visits.

\section{What do the new findings imply?}

- Government and non-governmental organisations in Benin should implement comprehensive childhood healthcare programmes that can deal with the influence of socio-economic and proximate factors, particularly PNC visits, on deaths in under-five children in the short term.

(SDG-3), which focusses on ensuring healthy lives and promoting the well-being for all by $2030 .{ }^{1}$ Death of under-five children remains a subject of great concern to policymakers, public health experts and demographers, and it constitutes a measure of progress in the development of societies globally. For policymakers, it is an indication of efforts by countries to achieve their macroeconomic and public health priorities while, at the same time, upholding their values. ${ }^{2}$ For public health experts, it measures the level and extent of improvements or otherwise in child health and well-being of a nation, and the strength of its health system as a whole, ${ }^{3}$ while demographers may also see under-five mortality as an indicator of population growth or otherwise. ${ }^{4}$

Despite the significant reduction in underfive deaths globally between 1990 and 2016, it 
remains a critical public health concern for low-income and middle-income countries. Deaths of under-five children are more pronounced in sub-Saharan African countries like Benin. ${ }^{5}$ Although the rates have continued to decrease, it is still higher than other regions. ${ }^{5}{ }^{6}$ From 1990 to 2016, deaths in under-five children decreased from 93 to 41 deaths per 1000 live births globally and this constituted a $56 \%$ reduction in deaths in underfive children. Comparatively, under-five mortality rate was 79 deaths per 1000 live births in sub-Saharan Africa. Between the same period, Benin recorded a reduction in under-five mortality rate from 178 to 98 per 1000 live births. ${ }^{5}$ However, this reduction was far below the then Millennium Development Goal-4 (MDG-4) target, that sought to decrease deaths in under-five children by twothirds between 1990 and 2015. ${ }^{7}$

According to $\mathrm{WHO}^{8}$, preterm birth complications, intrapartum-related complications, acute respiratory infections, congenital anomalies and diarrhoea remain the major causes of death in under-five children . Among the strategies recommended for preventing under-five mortality are access to nutrition and micronutrients; exclusive breastfeeding; and skilled antenatal, birth and postnatal care. ${ }^{9}$ Others include encouraging immunisation and enhancing access to water, sanitation and hygiene. ${ }^{8}$ However, previous studies have shown that most of these interventions are beyond the reach of a number of low-income and middle-income countries, like Benin. ${ }^{10-13}$ A recent report by $\mathrm{UNICEF}^{6}$ noted that Benin is among the countries that are making little progress in reducing deaths in under-five children, with the current rate at 93 per 1000 live births.

In Benin, the national prevalence of under-five overweight increased from $1.7 \%$ in 2014 to $1.9 \%$ in 2018 while under-five stunting and wasting were $32.2 \%$ and $5 \%$, respectively. Exclusive breastfeeding of children under 6 months was $41.4 \%$ in 2018 while the prevalence of low birth weight was $16.9 \%$. $^{14}$ In terms of maternal healthcare utilisation, a recent study in Benin showed that the percentage of at least four antenatal care (ANC) visits decreased from $61.4 \%$ to $61.1 \%$, while facility-based delivery increased from $88.6 \%$ to $93.5 \%$ between 2006 and 2012. In terms of postnatal care, there was only a slight increase from $15.2 \%$ in 2006 to $18.4 \%$ in 2012 . All these factors may contribute to the current prevalence of under-five mortality, hence an insight into factors that influence under-five mortality is warranted.

The factors that influence under-five mortality are generally known in sub-Saharan Africa. ${ }^{2}{ }^{15-17}$ However, their level of influence differ across countries. ${ }^{16} 1819$ Nonetheless, there are limited studies on predictors of under-five mortality in Benin. The few studies that have looked at this phenomenon examined the determinants of under-five mortality using multiple countries in Africa, which include Benin. ${ }^{15} 1720$ The gap in these studies is the inadequate information on factors that contribute to under-five mortality. For instance, prior studies have focussed on socio-economic determinants, ${ }^{16} 181921$ with little emphasis on proximate determinants. Proximate determinants are the behavioural and biological factors through which socio-economic factors affect mortality, ${ }^{22}$ but there is no empirical evidence on how these factors could offer possible explanations for the high prevalence of death in under-five children in the country based on a nationally representative data. Hence, the present study examined how proximate and socio-economic factors are associated with under-five mortality in Benin.

\section{METHODS}

\section{Study design}

Data from the 2017 to 2018 Benin Demographic and Health Surveys (BDHS) was used in this study. Specifically, the birth recode file, which contains data of all births, was used. Data of 5977 under-five children, which formed the unit of analysis in this study, were obtained by interviewing women who had given birth within 5 years to the survey. The BDHS used a multistage, stratified sampling design in selecting all eligible women and men for interviews from households that were considered as sampling units. ${ }^{23}$

\section{Conceptual framework}

This study adapted Mosley and Chen's conceptual framework of child survival in developing countries (figure 1$)^{22}$ as its conceptual framework. The framework helped in selecting variables available in the 2017 to 2018 BDHS datasets for the analyses. The adapted constructs of the conceptual framework are shown in figure 1 .

\section{Outcome variable}

The outcome variable was under-five mortality, defined as the death of a child within the first 5 years of life. We re-coded it into a binary variable as $(0=\mathrm{No}$ and $1=\mathrm{Yes})$.

\section{Explanatory variables}

The explanatory variables considered in this study include community-level and household-level/individual-level socio-economic variables and proximate determinants variables. The community-level socio-economic variables include region and place of residence. The householdlevel and individual-level socio-economic variables were wealth index, mother's ethnicity, mother's religion, maternal education and occupation, and partner's education and occupation. The proximate determinants include sex of child, birth size, birth rank and birth interval, mother's age at childbirth, ANC visit, tobacco use, place of delivery, type of assistance during delivery and postnatal check-up (PNC) visits. The various categories for these determinants can be found in table 1 .

\section{Analytical strategy}

Descriptive and multiple regression analyses were performed in this study. The first step of the analyses involved the use of frequency tabulations to describe the proportions of all the explanatory variables, followed by a distribution of under-five mortality per the explanatory 


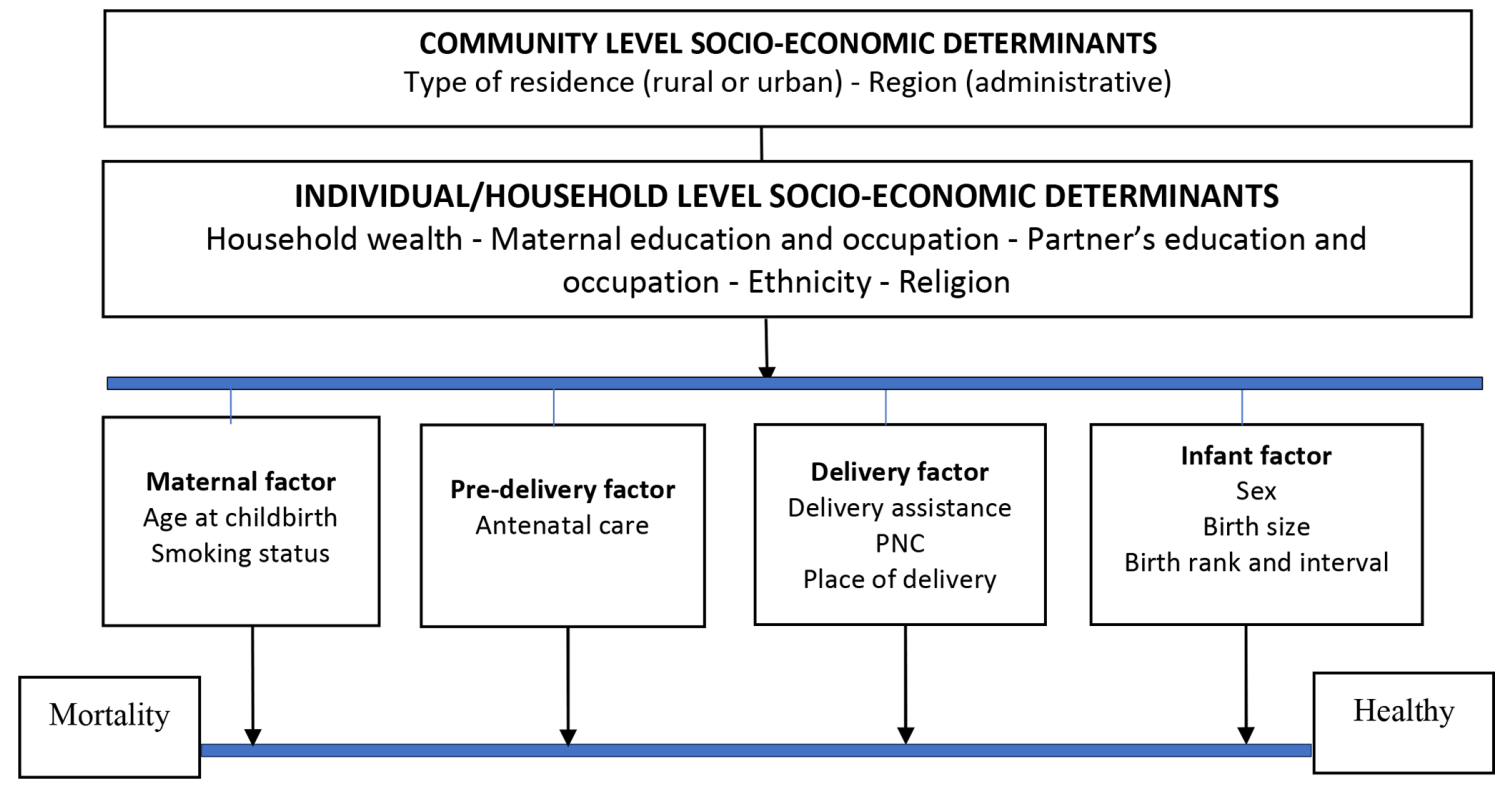

Figure 1 Conceptual framework of determinants of under-five mortality Source. ${ }^{22}$ PNC, postnatal check-up.

variables, with their respective CIs. Then, we conducted a bivariate logistic regression analysis with each of the explanatory variables and the outcome variable (underfive mortality) to assess the link between all the potential determinants and deaths in under-five children without adjusting for the effect of other covariates. This was followed by a multicollinearity test on all the explanatory variables to determine if there was evidence of multicollinearity.

Using the variance inflation factor (VIF), the multicollinearity test results indicated no collinearity among the explanatory variables (mean $\mathrm{VIF}=1.49$, max $\mathrm{VIF}=1.66$ and minimum=1.01). Next, we performed a multivariable hierarchical logistic regression analysis in three stages. First, community-level socio-economic determinants variables were fitted in the first model to assess their association with under-five mortality (Model I). This was followed by the inclusion of household-level/individual-level socio-economic variables (Model II). Proximate determinants variables were added in the final model to also examine their association with deaths in under-five children (Model III). Categories of the explanatory variables that had the lowest under-five mortality rates were used as reference categories. The goodness-of-fit of the logistic models was assessed using Pseudo $\mathrm{R}^{2}$. Data processing and analysis were performed using Stata, V.14.2 (Stata Corp, College Station, Texas, USA). We further applied sample weight (v005/1000 000) to correct for oversampling and undersampling. The SVY command in Stata was used to account for the complex survey design and generalisability of the findings. We further used the 'syncmrates' command to calculate the under-five mortality rates using the synthetic cohort probability. ${ }^{15}$

\section{Patient and public involvement}

Patients and the public were not involved in the design and conduct of this research.

\section{RESULTS}

This study includes 5977 under-five children. Table 1 shows results on the characteristics and the distribution of under-five mortality. Majority of the children were from the Alibori region (14.0\%) while only $4.0 \%$ were from the Littoral region. A greater proportion of the children were from rural areas $(63.0 \%)$, middle wealth quintile households $(21.1 \%)$, Fon ethnic group $(35.0 \%)$ and Christians (51.2\%). Approximately $57.0 \%$ of the children were average in size, $50.0 \%$ were males and $50.0 \%$ females. Approximately $44 \%$ were born with $\geq 4$ birth rank and $>2$ years of birth interval. Under-five mortality was found to be 96 deaths per 1000 live births in the country. Deaths of under-five children was 133 per 1000 live births in the Donga region compared with 44 deaths per 1000 live birth in the Littoral region. Relatedly, under-five mortality was higher in the rural areas (106 deaths per 1000 live births) compared with the urban areas (81 deaths per 1000 live births). Children from poorer households experienced a higher under-five mortality rate (123 deaths per 1000 live births) compared with those from richest households (58 deaths per 1000 live births). Children who were very small at birth had higher under-five mortality rate (163 deaths per 1000 live births) than those with larger than average size at birth (83 deaths per 1000 live births). Under-five mortality was high in children with 2 to 3 birth rank and $\leq 2$ years of birth interval (109 deaths per 1000 live births) compared with those with $\geq 4$ birth rank and $\leq 2$ years of birth interval (77 deaths per 1000 live births). Regarding the sex of the child, under-five mortality was high among males (98 per 1000 live births) compared with females (83 per 1000 live births).

Table 1 further shows results of the unadjusted odds ratios (uORs) of the determinants of under-five mortality. Variations in the likelihood of under-five mortality by 
Table 1 U5MR (per 1000 live births) and uOR by explanatory variables ( $n=5977$, weighted)

\begin{tabular}{|c|c|c|c|c|c|}
\hline \multirow[b]{2}{*}{ Determinants } & \multirow[b]{2}{*}{$\mathrm{N}$, weighted } & \multirow[b]{2}{*}{ Per cent } & \multirow{2}{*}{$\begin{array}{l}\text { U5MR } \\
(95 \% \mathrm{Cl}) \\
\end{array}$} & \multicolumn{2}{|c|}{ Bivariate logistic regression } \\
\hline & & & & UOR & $95 \% \mathrm{Cl}$ \\
\hline \multicolumn{6}{|l|}{ Region } \\
\hline Alibori & 840 & 14.1 & 91 (67 to 116$)$ & 1.76 & 1.71 to 4.36 \\
\hline Atacora & 498 & 8.3 & 114 (97 to 120$)$ & 1.77 & 0.69 to 4.54 \\
\hline Atlantic & 601 & 10.1 & $106(87$ to 125$)$ & 1.93 & 0.75 to 4.94 \\
\hline Borgou & 728 & 12.2 & 79 (67 to 92$)$ & 1.97 & 0.80 to 4.84 \\
\hline Collines & 420 & 7.0 & 88 (64 to 112$)$ & 2.14 & 0.85 to 5.42 \\
\hline Couffo & 425 & 7.1 & 90 (65 to 114$)$ & 1.75 & 0.66 to 4.66 \\
\hline Donga & 349 & 5.8 & 133 (111 to 154$)$ & $2.66^{*}$ & 1.04 to 6.82 \\
\hline Littoral & 230 & 3.9 & 44 (29 to 59$)$ & 1 & - \\
\hline Mono & 277 & 4.6 & $106(71$ to 141$)$ & 2.05 & 0.75 to 5.61 \\
\hline Ouémé & 528 & 8.8 & 78 (59 to 96$)$ & 2.01 & 0.78 to 5.18 \\
\hline Plateau & 417 & 7.0 & 130 (100 to 159$)$ & $3.86^{* *}$ & 1.57 to 9.46 \\
\hline Zou & 664 & 11.1 & 97 (76 to 117$)$ & 1.95 & 0.78 to 4.86 \\
\hline
\end{tabular}

Type of place of residence

\begin{tabular}{|c|c|c|c|c|c|}
\hline Urban & 2243 & 37.5 & 81 (70 to 91 ) & 1 & - \\
\hline Rural & 3734 & 62.5 & 106 (98 to 114$)$ & $1.47^{*}$ & 1.09 to 1.98 \\
\hline \multicolumn{6}{|l|}{ Wealth index } \\
\hline Poorest & 1236 & 20.7 & 102 (87 to 116$)$ & 1.54 & 0.93 to 2.56 \\
\hline Poorer & 1232 & 20.6 & $123(110$ to 136$)$ & $2.31^{* * *}$ & 1.43 to 3.73 \\
\hline Middle & 1259 & 21.1 & 97 (85 to 109) & 1.60 & 0.96 to 2.66 \\
\hline Richer & 1190 & 19.9 & 95 (84 to 106) & $1.79^{*}$ & 1.08 to 2.96 \\
\hline Richest & 1059 & 17.7 & 58 (46 to 69 ) & 1 & - \\
\hline \multicolumn{6}{|l|}{ Ethnicity } \\
\hline Adja & 794 & 13.3 & 93 (75 to 110$)$ & 0.82 & 0.47 to 1.44 \\
\hline Bariba & 837 & 14.0 & 83 (70 to 97$)$ & 0.68 & 0.38 to 1.22 \\
\hline Dendi & 396 & 6.6 & 133 (100 to 166$)$ & 1.09 & 0.58 to 2.07 \\
\hline Fon & 2084 & 34.9 & 89 (80 to 99 ) & 0.91 & 0.57 to 2.07 \\
\hline Yoa and Lokpa & 190 & 3.2 & 156 (126 to 185$)$ & 1.67 & 0.82 to 3.39 \\
\hline Betamaribe & 385 & 6.4 & 104 (90 to 117 ) & 0.55 & 0.25 to 1.19 \\
\hline Peulh & 616 & 10.3 & 82 (66 to 98 ) & 1 & - \\
\hline Yoruba & 674 & 11.3 & 103 (85 to 120$)$ & 1.16 & 0.68 to 1.97 \\
\hline \multicolumn{6}{|l|}{ Religion } \\
\hline Christianity & 3061 & 51.2 & 92 (83 to 102) & 1 & - \\
\hline Islam & 1908 & 31.9 & 98 (86 to 110$)$ & 1.05 & 0.77 to 1.44 \\
\hline Others & 1008 & 16.9 & 105 (93 to 116$)$ & 1.16 & 0.80 to 1.67 \\
\hline \multicolumn{6}{|l|}{$\begin{array}{l}\text { Highest educational } \\
\text { level of mother }\end{array}$} \\
\hline No education & 3891 & 65.1 & 103 (95 to 110$)$ & $1.66^{*}$ & 1.07 to 2.57 \\
\hline Primary & 1086 & 18.2 & 88 (74 to 102$)$ & 1.50 & 0.89 to 2.51 \\
\hline Secondary/higher & 1000 & 16.7 & 68 (55 to 81 ) & 1 & - \\
\hline \multicolumn{6}{|l|}{$\begin{array}{l}\text { Highest educational } \\
\text { level of father }\end{array}$} \\
\hline No education & 3246 & 54.3 & 101 (91 to 111$)$ & $1.75^{* *}$ & 1.20 to 2.55 \\
\hline Primary & 1259 & 21.1 & 102 (91 to 113 ) & $1.67^{*}$ & 1.07 to 2.60 \\
\hline
\end{tabular}


Table 1 Continued

\begin{tabular}{|c|c|c|c|c|c|}
\hline \multirow[b]{2}{*}{ Determinants } & \multirow[b]{2}{*}{$\mathbf{N}$, weighted } & \multirow[b]{2}{*}{ Per cent } & \multirow{2}{*}{$\begin{array}{l}\text { U5MR } \\
\text { (95\% CI) }\end{array}$} & \multicolumn{2}{|c|}{ Bivariate logistic regression } \\
\hline & & & & uOR & $95 \% \mathrm{Cl}$ \\
\hline Secondary/higher & 1472 & 24.6 & 72 (61 to 83$)$ & 1 & - \\
\hline \multicolumn{6}{|l|}{ Mother's occupation } \\
\hline Not working & 966 & 16.2 & 92 (78 to 106$)$ & 0.82 & 0.33 to 2.03 \\
\hline Official & 193 & 3.2 & 67 (35 to 99) & 1 & - \\
\hline $\begin{array}{l}\text { Sales and } \\
\text { services }\end{array}$ & 2716 & 45.4 & 95 (86 to 105$)$ & 1.25 & 0.54 to 2.89 \\
\hline Agricultural & 1380 & 23.1 & 106 (93 to 109) & 1.20 & 0.51 to 2.83 \\
\hline Manual & 722 & 12.1 & 90 (72 to 109) & 1.50 & 0.62 to 3.65 \\
\hline \multicolumn{6}{|l|}{ Father's occupation } \\
\hline Not working & 119 & 2.0 & 109 (87 to 132) & 0.32 & 0.04 to 2.39 \\
\hline Official & 838 & 14.0 & 73 (56 to 90$)$ & 1 & - \\
\hline $\begin{array}{l}\text { Sales and } \\
\text { services }\end{array}$ & 1356 & 22.7 & 86 (74 to 99) & 1.42 & 0.83 to 2.42 \\
\hline Agricultural & 2658 & 44.5 & 109 (98 to 119) & $1.68^{*}$ & 1.03 to 2.71 \\
\hline Manual & 1007 & 16.9 & 90 (77 to 103$)$ & $1.75^{*}$ & 1.01 to 3.00 \\
\hline \multicolumn{6}{|l|}{ Size of child at birth } \\
\hline Very large & 674 & 11.3 & 102 (76 to 127$)$ & 0.93 & 0.57 to 1.51 \\
\hline $\begin{array}{l}\text { Larger than } \\
\text { average }\end{array}$ & 1040 & 17.4 & 83 (67 to 98$)$ & 1 & - \\
\hline Average & 3432 & 57.4 & 89 (80 to 99) & 0.71 & 0.50 to 1.01 \\
\hline $\begin{array}{l}\text { Smaller than } \\
\text { average }\end{array}$ & 618 & 10.3 & $91(71$ to 111$)$ & 0.91 & 0.55 to 1.50 \\
\hline Very small & 213 & 3.6 & 163 (123 to 202) & 1.32 & 0.69 to 2.54 \\
\hline \multicolumn{6}{|l|}{ Sex of the child } \\
\hline Male & 3008 & 50.3 & 98 (89 to 107) & 1.01 & 0.77 to 1.32 \\
\hline Female & 2969 & 49.7 & 83 (73 to 93 ) & 1 & - \\
\hline \multicolumn{6}{|l|}{$\begin{array}{l}\text { Birth rank and birth } \\
\text { interval }\end{array}$} \\
\hline First birth rank & 1094 & 18.3 & 80 (68 to 91$)$ & 1.14 & 0.73 to 1.79 \\
\hline $\begin{array}{l}2 \text { to } 3 \text { birth rank } \\
\text { and } \leq 2 \text { years of } \\
\text { birth interval }\end{array}$ & 420 & 7.0 & 109 (86 to 128$)$ & 1.33 & 0.74 to 2.40 \\
\hline $\begin{array}{l}\geq 4 \text { birth rank and } \\
>2 \text { years of birth } \\
\text { interval }\end{array}$ & 2609 & 43.6 & 85 (76 to 94$)$ & $1.70^{* \star}$ & 1.21 to 2.39 \\
\hline $\begin{array}{l}\geq 4 \text { birth rank and } \\
\leq 2 \text { years of birth } \\
\text { interval }\end{array}$ & 1855 & 31.0 & 77 (69 to 86 ) & 1 & - \\
\hline \multicolumn{6}{|l|}{$\begin{array}{l}\text { Age of mother at } \\
\text { childbirth }\end{array}$} \\
\hline$<20$ years & 3069 & 51.4 & 102 (87 to 117 ) & 1.24 & 0.94 to 1.63 \\
\hline 20 to 40 years & 2908 & 48.7 & 83 (71 to 95) & 1 & - \\
\hline \multicolumn{6}{|l|}{ Antenatal care visit } \\
\hline No & 591 & 9.9 & 118 (74 to 161$)$ & 1.35 & 0.91 to 2.02 \\
\hline Yes & 5386 & 90.1 & 61 (50 to 72 ) & 1 & - \\
\hline \multicolumn{6}{|l|}{ Use of tobacco } \\
\hline No & 5885 & 98.5 & 93 (84 to 101) & 1 & - \\
\hline
\end{tabular}


Table 1 Continued

\begin{tabular}{|c|c|c|c|c|c|}
\hline \multirow[b]{2}{*}{ Determinants } & \multirow[b]{2}{*}{$\mathrm{N}$, weighted } & \multirow[b]{2}{*}{ Per cent } & \multirow{2}{*}{$\begin{array}{l}\text { U5MR } \\
(95 \% \mathrm{Cl})\end{array}$} & \multicolumn{2}{|c|}{ Bivariate logistic regression } \\
\hline & & & & uOR & $95 \% \mathrm{Cl}$ \\
\hline Yes & 92 & 1.5 & 100 (46 to 155$)$ & 1.85 & 0.80 to 4.27 \\
\hline \multicolumn{6}{|l|}{ Place of delivery } \\
\hline Home & 827 & 13.8 & 105 (75 to 135$)$ & 1.05 & 0.72 to 1.54 \\
\hline Health facility & 5150 & 86.2 & 90 (82 to 99) & 1 & - \\
\hline \multicolumn{6}{|l|}{ Delivery assistance } \\
\hline By TBA/Others & 1000 & 16.7 & 104 (78 to 131$)$ & 0.95 & 0.66 to 1.38 \\
\hline $\begin{array}{l}\text { By Skilled Birth } \\
\text { Attendant/health } \\
\text { professional }\end{array}$ & 4977 & 83.3 & 90 (81 to 98$)$ & 1 & - \\
\hline \multicolumn{6}{|l|}{$\begin{array}{l}\text { Postnatal check of } \\
\text { visits }\end{array}$} \\
\hline No & 1841 & 30.8 & 96 (74 to 118$)$ & $1.42^{*}$ & 1.06 to 1.89 \\
\hline$<24$ hours & 3791 & 63.4 & 60 (46 to 73 ) & 1 & - \\
\hline$\geq 1$ day & 345 & 5.8 & 61 (35 to 84) & 1.39 & 0.81 to 2.36 \\
\hline National total & 5977 & & 96 (90 to 102) & & \\
\hline
\end{tabular}

${ }^{*} \mathrm{p}<0.05 ;{ }^{* *} \mathrm{p}<0.01 ;$ and ${ }^{* * *} \mathrm{p}<0.001$.

U5MR, under-five mortality rate; uOR, unadjusted OR.

region and place of residence was found, with a high likelihood of deaths in under-five children in the Plateau region (uOR=3.86, 95\% CI: 1.57 to 9.46) and rural areas $(\mathrm{uOR}=1.47,95 \%$ CI: 1.09 to 1.98$)$. The likelihood of death in under-five children was high in children of mothers with poorest wealth quintile $(\mathrm{uOR}=2.31,95 \%$ CI: 0.93 to 2.56) and mothers with no formal education (uOR=1.66, 95\% CI: 1.07 to 2.57). Similarly, underfive mortality was high in children whose fathers had no education ( $\mathrm{uOR}=1.75,95 \% \mathrm{CI}: 1.20$ to 2.55 ) and engaged in manual work ( $\mathrm{uOR}=1.75,95 \%$ CI: 1.01 to $3.00)$. Similarly, children of $\geq 4$ birth rank and $>2$ years of birth interval were more likely to die before age five, compared with those with a first birth rank $(\mathrm{uOR}=1.70$, 95\% CI: 1.21 to 2.39). Children born to mothers who had no PNC had higher odds of dying compared with those whose PNC visits occurred in $<24$ hours ( $\mathrm{uOR}=1.42,95 \%$ CI: 1.06 to 1.89 ).

Table 2 shows results of the multivariable hierarchical logistic regression analysis. In Model I, the association between all the community-level variables and underfive mortality was assessed. The results revealed that the likelihood of death were higher in children born in the Plateau region (adjusted OR $(\mathrm{aOR})=3.05,95 \%$ CI: 1.29 to 7.64) compared with those born in the Littoral region. Similarly, under-five mortality was high in children born in the rural areas $(\mathrm{aOR}=1.45,95 \%$ CI: 1.09 to 1.98$)$ than those born in the urban areas (Model I). In Model II, all the individual-level/household-level variables were included for further analyses. The results showed no statistically significant associations between communitylevel determinants and individual-level/household-level variables and under-five mortality. In Model III, all the proximate determinant variables were included in the analysis. In this model, the community-level determinants that were significant in Model 1 were lost. However, two of the proximate determinants (ie, birth rank and birth interval, and PNC visits) showed statistically significant associations with under-five mortality. We found the likelihood of death to be higher among children with $\geq 4$ birth rank and $\leq 2$ years of birth interval, $1.52(95 \% \mathrm{CI}$ : 1.07 to 2.17 ) than those with $\geq 4$ birth rank and $>2$ years birth interval. Relatedly, the odds of dying was higher in children whose mothers had no PNC visits after delivery compared with those whose mothers had PNC visits less than 24 hours after delivery ( $\mathrm{aOR}=1.79,95 \% \mathrm{CI}$ : 1.22 to 2.63).

\section{DISCUSSION}

We examined the proximate and socio-economic predictors of death in under-five children in Benin. Regarding socio-economic determinants, this study found the likelihood of death in under-five children to be higher in the Plateau region. The regional disparity in underfive mortality in Benin can be attributed to disparities in access to and utilisation of maternal healthcare services in the country. ${ }^{24}$ An evaluation of the health system in Benin revealed that the Plateau region is one of the regions with the lowest key healthcare personnel such as doctors, nurses and midwives. ${ }^{25}$ Furthermore, healthcare facilities in the region were also found to be few compared with regions like Atacora and Couffo. ${ }^{25}$ Similar studies on predictors of death in children in subSaharan Africa have also identified regional disparities in neonatal, infant and under-five mortality. ${ }^{18} 1926$ 
Table 2 Multivariable logistic regression results for determinants of under-five mortality in the 5 years preceding the survey$\mathrm{aOR}$

\begin{tabular}{|c|c|c|c|c|c|c|}
\hline \multirow[b]{2}{*}{ Determinants } & \multicolumn{2}{|c|}{ Model I } & \multicolumn{2}{|l|}{ Model II } & \multicolumn{2}{|c|}{ Model III } \\
\hline & aOR & $95 \% \mathrm{Cl}$ & aOR & $95 \% \mathrm{Cl}$ & aOR & $95 \% \mathrm{Cl}$ \\
\hline \multicolumn{7}{|l|}{ Region } \\
\hline Alibori & 1.31 & 0.51 to 3.36 & 1.19 & 0.39 to 3.70 & 1.23 & 0.39 to 3.87 \\
\hline Atacora & 1.39 & 0.52 to 3.69 & 1.95 & 0.59 to 6.52 & 1.46 & 0.43 to 5.00 \\
\hline Atlantic & 1.49 & 0.58 to 3.86 & 1.11 & 0.40 to 3.05 & 0.97 & 0.34 to 2.74 \\
\hline Borgou & 1.52 & 0.60 to 3.85 & 1.54 & 0.50 to 4.75 & 1.40 & 0.45 to 4.38 \\
\hline Collines & 1.61 & 0.61 to 4.24 & 1.37 & 0.47 to 3.98 & 1.33 & 0.45 to 3.90 \\
\hline Couffo & 1.33 & 0.48 to 3.69 & 1.06 & 0.31 to 3.57 & 1.00 & 0.29 to 3.43 \\
\hline Donga & 2.15 & 0.82 to 5.64 & 1.34 & 0.39 to 4.57 & 1.33 & 0.39 to 4.62 \\
\hline Littoral & 1 & - & 1 & - & 1 & - \\
\hline Mono & 1.62 & 0.58 to 4.51 & 1.22 & 0.37 to 3.99 & 1.06 & 0.31 to 3.58 \\
\hline Ouémé & 1.68 & 0.64 to 4.44 & 1.26 & 0.44 to 3.60 & 1.23 & 0.43 to 3.55 \\
\hline Plateau & $3.05^{*}$ & 1.29 to 7.64 & 2.43 & 0.85 to 6.90 & 2.26 & 0.78 to 6.52 \\
\hline Zou & 1.48 & 0.59 to 3.75 & 1.07 & 0.39 to 2.97 & 1.15 & 0.41 to 3.25 \\
\hline \multicolumn{7}{|c|}{ Type of place of residence } \\
\hline Urban & 1 & - & 1 & - & 1 & - \\
\hline Rural & $1.45^{*}$ & 1.07 to 1.98 & 1.32 & 0.94 to 1.85 & 1.36 & 0.97 to 1.90 \\
\hline \multicolumn{7}{|l|}{ Wealth index } \\
\hline Poorest & & & 1.08 & 0.56 to 2.10 & 1.00 & 0.51 to 1.96 \\
\hline Poorer & & & 1.60 & 0.86 to 2.98 & 1.51 & 0.81 to 2.85 \\
\hline Middle & & & 1.12 & 0.60 to 2.10 & 1.06 & 0.56 to 1.98 \\
\hline Richer & & & 1.31 & 0.73 to 2.35 & 1.27 & 0.70 to 2.30 \\
\hline Richest & & & 1 & - & 1 & - \\
\hline \multicolumn{7}{|l|}{ Ethnicity } \\
\hline Adja & & & 0.97 & 0.33 to 2.90 & 1.04 & 0.35 to 3.10 \\
\hline Bariba & & & 0.66 & 0.35 to 1.26 & 0.68 & 0.36 to 1.29 \\
\hline Dendi & & & 1.52 & 0.69 to 3.39 & 1.56 & 0.69 to 3.53 \\
\hline Fon & & & 1.06 & 0.44 to 2.53 & 1.12 & 0.47 to 2.69 \\
\hline Yoa and Lokpa & & & 0.97 & 0.87 to 4.47 & 2.32 & 0.97 to 5.51 \\
\hline Betamaribe & & & 0.39 & 0.14 to 1.06 & 0.43 & 0.16 to 1.18 \\
\hline Peulh & & & 1 & - & 1 & - \\
\hline Yoruba & & & 0.93 & 0.37 to 2.31 & 1.00 & 0.40 to 1.18 \\
\hline \multicolumn{7}{|l|}{ Religion } \\
\hline Christianity & & & 1 & - & 1 & - \\
\hline Islam & & & 0.89 & 0.57 to 1.39 & 0.91 & 0.57 to 1.43 \\
\hline Others & & & 1.18 & 0.79 to 1.76 & 1.16 & 0.77 to 1.73 \\
\hline \multicolumn{7}{|c|}{ Highest educational level of mother } \\
\hline No education & & & 1.12 & 0.65 to 1.92 & 1.01 & 0.58 to 1.78 \\
\hline Primary & & & 1.09 & 0.61 to 1.97 & 1.05 & 0.58 to 1.90 \\
\hline Secondary/higher & & & 1 & - & 1 & - \\
\hline \multicolumn{7}{|c|}{ Highest educational level of father } \\
\hline No education & & & 1.37 & 0.87 to 2.17 & 1.33 & 0.85 to 2.10 \\
\hline Primary & & & 1.32 & 0.81 to 2.13 & 1.28 & 0.79 to 2.08 \\
\hline Secondary/higher & & & 1 & - & 1 & - \\
\hline \multicolumn{7}{|c|}{ Mother's occupation } \\
\hline Not working & & & 0.45 & 0.16 to 1.31 & 0.40 & 0.14 to 1.15 \\
\hline Official & & & 1 & - & 1 & - \\
\hline Sales and services & & & 0.71 & 2.71 to 1.87 & 0.64 & 0.24 to 1.69 \\
\hline
\end{tabular}


BMJ Global Health

Table 2 Continued

\begin{tabular}{|c|c|c|c|c|c|c|}
\hline \multirow[b]{2}{*}{ Determinants } & \multicolumn{2}{|c|}{ Model I } & \multicolumn{2}{|l|}{ Model II } & \multicolumn{2}{|c|}{ Model III } \\
\hline & aOR & $95 \% \mathrm{CI}$ & aOR & $95 \% \mathrm{Cl}$ & aOR & $95 \% \mathrm{Cl}$ \\
\hline Agricultural & & & 0.59 & 0.21 to 1.64 & 0.52 & 0.19 to 1.48 \\
\hline Manual & & & 0.89 & 0.32 to 2.48 & 0.84 & 0.30 to 2.34 \\
\hline \multicolumn{7}{|l|}{ Father's occupation } \\
\hline Not working & & & 0.34 & 0.05 to 2.57 & 0.30 & 0.04 to 2.35 \\
\hline Official & & & 1 & - & 1 & - \\
\hline Sales and services & & & 1.23 & 0.69 to 2.22 & 1.24 & 0.69 to 2.23 \\
\hline Agricultural & & & 1.41 & 0.78 to 2.54 & 1.40 & 0.78 to 2.53 \\
\hline Manual & & & 1.50 & 0.85 to 2.66 & 1.48 & 0.83 to 2.63 \\
\hline \multicolumn{7}{|l|}{ Size of child at birth } \\
\hline Very large & & & & & 0.99 & 0.60 to 1.62 \\
\hline Larger than average & & & & & 1 & - \\
\hline Average & & & & & 0.75 & 0.52 to 1.10 \\
\hline Smaller than average & & & & & 0.92 & 0.54 to 1.58 \\
\hline Very small & & & & & 1.36 & 0.69 to 2.69 \\
\hline \multicolumn{7}{|l|}{ Sex of the child } \\
\hline Male & & & & & 1.01 & 0.76 to 1.34 \\
\hline Female & & & & & 1 & - \\
\hline \multicolumn{7}{|l|}{ Birth rank and birth interval } \\
\hline First birth rank & & & & & 1.28 & 0.82 to 2.00 \\
\hline $\begin{array}{l}2 \text { to } 3 \text { birth rank and } \leq 2 \text { years of birth } \\
\text { interval }\end{array}$ & & & & & 1.39 & 0.76 to 2.52 \\
\hline $\begin{array}{l}\geq 4 \text { birth rank and }>2 \text { years of birth } \\
\text { interval }\end{array}$ & & & & & $1.52^{*}$ & 1.07 to 2.17 \\
\hline $\begin{array}{l}\geq 4 \text { birth rank and } \leq 2 \text { years of birth } \\
\text { interval }\end{array}$ & & & & & 1 & - \\
\hline \multicolumn{7}{|l|}{ Age of mother at childbirth } \\
\hline$<20$ years & & & & & 1.14 & 0.86 to 1.52 \\
\hline 20 to 40 years & & & & & 1 & - \\
\hline \multicolumn{7}{|l|}{ Antenatal care visit } \\
\hline No & & & & & 1.49 & 0.89 to 2.51 \\
\hline Yes & & & & & 1 & - \\
\hline \multicolumn{7}{|l|}{ Use of tobacco } \\
\hline No & & & & & 1 & - \\
\hline Yes & & & & & 1.84 & 0.78 to 4.36 \\
\hline \multicolumn{7}{|l|}{ Place of delivery } \\
\hline Home & & & & & 0.71 & 0.31 to 1.59 \\
\hline Health facility & & & & & 1 & - \\
\hline \multicolumn{7}{|l|}{ Delivery assistance } \\
\hline By TBA/others & & & & & 0.72 & 0.35 to 1.45 \\
\hline By SBA/health professional & & & & & 1 & - \\
\hline \multicolumn{7}{|l|}{ Postnatal check of visits } \\
\hline No & & & & & $1.79^{* *}$ & 1.22 to 2.63 \\
\hline$<24$ hours & & & & & 1 & - \\
\hline$\geq 1$ day & & & & & 1.38 & 0.79 to 2.40 \\
\hline Pseudo $\mathrm{R}^{2}$ & 0.011 & & 0.030 & & 0.045 & \\
\hline
\end{tabular}

Exponentiated coefficients; $95 \% \mathrm{Cl}$ in bracket.

${ }^{*} \mathrm{p}<0.05,{ }^{* *} \mathrm{p}<0.01$.

aOR, adjusted OR. 
Similarly, we found that children born in rural areas had higher odds of experiencing death compared with those in the rural areas. Rural-urban disparity in underfive mortality has been explored in previous studies in sub-Saharan Africa ${ }^{2} 17$ and in country-specific studies within the sub-region. ${ }^{1627} 28$ Like the current study, most of these studies found under-five mortality to be higher in rural areas compared with urban areas. This disparity has been attributed to various factors, including inequities in the distribution and utilisation of healthcare services. For instance, Yaya et $a l^{17}$ explained that women who live in urban areas are more likely to make use of healthcare services and have better access to healthcare facilities, which can enhance their access to treatment for childhood illnesses, through timely and appropriate treatment. Ettarh and Kimani ${ }^{16}$ also attribute the high prevalence of death in under-five children in rural areas to the predominant negative sociocultural beliefs and practices, as well as individual-level characteristics such as low level of education and wealth status. However, these factors did not have any significant influence on underfive mortality in this current study.

Birth rank and birth interval, and PNC visits predicted under-five mortality in this study. Specifically, with the same birth rank, the odds of dying was higher in children with longer birth interval compared with those with shorter birth interval. These findings contradict previous studies that found shorter birth interval to be associated with a higher likelihood of child mortality. ${ }^{29-31}$ Further research is needed to explore this counterintuitive finding. Furthermore, our study revealed that children whose mothers had no PNC visits after delivery had higher odds of dying compared with those whose mothers had PNC visits in less than 24 hours after delivery. The results corroborate the findings of previous studies on the role of PNC visits in child mortality. ${ }^{32-34}$ Warren $e t a l^{35}$ provide some key reasons for the link between lack of PNC visits and deaths of children. They explained that low-to-no PNC visits negatively influences newborn and child health. This is because, absence of PNC visits hinders support for healthy home behaviours, such as breastfeeding, which can negatively impact children nutritional status. They further explained that during PNC visits, children are assessed for danger signs, their weights are measured and recorded, and their temperatures checked while mothers are also counselled on danger signs and home care. All these measures have been shown to reduce the odds of under-five mortality. ${ }^{34}$

\section{Strengths and limitations}

The use of nationally representative data and the analytical approaches which support the generalisability of the findings are the key strengths of this study. Nonetheless, the cross-sectional study design of this study shams the ability to adequately establish causality. Moreover, data on mortalities were obtained based on self-report, which can distort the accuracy of the results. This is because there may be a possibility of social desirability inherent with self-reporting from the respondents. For instance, there is the possibility of over-reporting stillbirths as under-five deaths. Under-reporting may also occur when collecting birth histories from mothers since some of them may find it difficult to reveal information on those unfortunate events.

\section{CONCLUSION}

This study has established that socio-economic and proximate determinants are important determinants of underfive mortality in Benin. Specifically, under-five mortality was found to be associated with children in the Plateau region and rural areas. Birth rank and birth interval, and PNC visits were significant proximate determinants of under-five mortality. Therefore, under-five mortality should be considered as a phenomenon that has multifactorial determinants. Our findings, therefore, have shown the need to implement socio-economic and proximate interventions, particularly those related to PNC visits when planning on under-five mortality. To achieve this, there is a need for a comprehensive, long-term public health interventions, which consider the disparity in the access and utilisation of healthcare services in Benin. Government and non-governmental organisations should consider immediate childhood healthcare programmes that can address the socio-economic and proximate determinants of under-five mortality, particularly, PNC visits in the short term.

Twitter Sanni Yaya @realSanniYaya and Edward Kwabena Ameyaw @edward ameyaw

Acknowledgements The authors thank the MEASURE DHS (Monitoring and Evaluation to Assess and Use Results Demographic and Health Surveys) project for their support and for free access to the original data.

Contributors SY contributed to the study design and conceptualisation. SY and BOA reviewed the literature and performed the analysis. EKA, AS, EKD and NKA provided technical support and critically reviewed the manuscript for its intellectual content. SY had final responsibility to submit for publication. All authors read and amended drafts of the paper, and approved the final version.

Funding The authors have not declared a specific grant for this research from any funding agency in the public, commercial or not-for-profit sectors.

Competing interests SY is editorial board member of this journal.

Patient and public involvement Patients and/or the public were not involved in the design, or conduct, or reporting, or dissemination plans of this research.

Patient consent for publication Not required.

Provenance and peer review Not commissioned; externally peer-reviewed.

Data availability statement Data are available in a public, open access repository. Data for this study were sourced from Demographic and Health surveys (DHS) and are available here: http://dhsprogram.com/data/available-datasets.cfm.

Open access This is an open access article distributed in accordance with the Creative Commons Attribution Non Commercial (CC BY-NC 4.0) license, which permits others to distribute, remix, adapt, build upon this work non-commercially, and license their derivative works on different terms, provided the original work is properly cited, appropriate credit is given, any changes made indicated, and the use is non-commercial. See: http://creativecommons.org/licenses/by-nc/4.0/.

\section{ORCID iDs}

Sanni Yaya http://orcid.org/0000-0002-4876-6043

Bright Opoku Ahinkorah http://orcid.org/0000-0001-7415-895X

Edward Kwabena Ameyaw http://orcid.org/0000-0002-6617-237X

Abdul-Aziz Seidu http://orcid.org/0000-0001-9734-9054 


\section{REFERENCES}

1 United Nations General Assembly. Transforming our world: the 2030 agenda for sustainable development. New York United Nations; 2015.

2 Yaya S, Bishwajit G, Okonofua F, et al. Under five mortality patterns and associated maternal risk factors in sub-Saharan Africa: a multicountry analysis. PLoS One 2018;13:e0205977.

3 Hill K, You D, Inoue M, et al. Child mortality estimation: accelerated progress in reducing global child mortality, 1990-2010. PLoS Med 2012;9:e1001303.

4 Roser M, Ritchie H, Dadonaite B. Child \& Infant Mortality. Our World in Data 2013.

5 UNICEF. Levels \& trends in child mortality: estimates developed by the UN inter-agency group for child mortality estimation. New York UN Interagency Group for Child Mortality Estimation; 2017.

6 UNICEF. Levels \& trends in child mortality: estimates developed by the UN inter-agency group for child mortality estimation. New York Estimation UIGfCM; 2019.

7 Hulme D. The Millennium Development Goals (MDGs): A Short History of the World's Biggest Promise. SSRN Journal 2009.

8 WHO. Causes of child mortality 2017.

9 Zhang Z, Tran NT, Nguyen TS, et al. Impact of maternal nutritional supplementation in conjunction with a breastfeeding support program during the last trimester to 12 weeks postpartum on breastfeeding practices and child development at 30 months old. PLoS One 2018;13:e0200519.

10 Kyei-Nimakoh M, Carolan-Olah M, McCann TV. Access barriers to obstetric care at health facilities in sub-Saharan Africa-a systematic review. Syst Rev 2017:6:110.

11 Wong KLM, Benova L, Campbell OMR. A look back on how far to walk: systematic review and meta-analysis of physical access to skilled care for childbirth in sub-Saharan Africa. PLoS One 2017;12:e0184432.

12 Geleto A, Chojenta C, Musa A, et al. Barriers to access and utilization of emergency obstetric care at health facilities in sub-Saharan Africa: a systematic review of literature. Syst Rev 2018;7:183.

13 Brown J, Cairncross S, Ensink JHJ. Water, sanitation, hygiene and enteric infections in children. Arch Dis Child 2013;98:629-34.

14 UNICEF. UNICEF global databases infant and young child feeding, UNICEF/WHO/World bank group: joint child malnutrition estimates, NCD risk factor collaboration, WHO global health Observatory and global burden of disease, the Institute for health metrics and evaluation. New York UNICEF; 2019.

15 Bado AR, Appunni SS. Decomposing wealth-based inequalities in under-five mortality in West Africa. Iran J Public Health 2015;44:920.

16 Ettarh RR, Kimani J. Determinants of under-five mortality in rural and urban Kenya. Rural Remote Health 2012;12:1812.

17 Yaya S, Uthman OA, Okonofua F, et al. Decomposing the rural-urban gap in the factors of under-five mortality in subSaharan Africa? Evidence from 35 countries. BMC Public Health 2019;19:616.
18 Adedini SA, Odimegwu C, Imasiku ENS, et al. Regional variations in infant and child mortality in Nigeria: a multilevel analysis. J Biosoc Sci 2015;47:165-87.

19 Honwana FE, Melesse SF. Socio-Economic and demographic determinants of under-five mortality in Ethiopia, 2011. Open Public Health J 2017;10:160-6.

20 Garenne M, Gakusi E. Under five mortality trends in Africa: reconstruction from demographic sample surveys. DHS Working Paper Series 2005;26.

21 Yaya S, Ekholuenetale M, Tudeme G, et al. Prevalence and determinants of childhood mortality in Nigeria. BMC Public Health 2017; $17: 485$

22 Mosley WH, Chen LC. An analytical framework for the study of child survival in developing countries. Popul Dev Rev 1984;10:25-45.

23 National Institute of Statistics and Economic Analysis INSAE and ICF. Demographic and health survey in Benin, 2017-2018. Cotonou, Benin and Rockville, Maryland, USA INSAE and ICF; 2019.

24 Yaya S, Uthman OA, Amouzou A, et al. Inequalities in maternal health care utilization in Benin: a population based cross-sectional study. BMC Pregnancy Childbirth 2018;18:194.

25 Adeya G, Bigirimana A, Cavanaugh K. Rapid assessment of the health system in Benin: April 2006. submitted to the US agency for international development; 2007.

26 Skaftun EK, Ali M, Norheim OF. Understanding inequalities in child health in Ethiopia: health achievements are improving in the period 2000-2011. PLoS One 2014;9:e106460.

27 Kanmiki EW, Bawah AA, Agorinya I, et al. Socio-Economic and demographic determinants of under-five mortality in rural Northern Ghana. BMC Int Health Hum Rights 2014;14:24.

28 Factors that affect under-five mortality among South African children: analysis of the South African demographic and health survey data set; 2009.

29 Kozuki N, Walker N. Exploring the association between short/long preceding birth intervals and child mortality: using reference birth interval children of the same mother as comparison. BMC Public Health 2013;13 Suppl 3:S6.

30 Molitoris J. The effect of birth spacing on child mortality in Sweden, 1878-1926. Popul Dev Rev 2017;43:61-82.

31 Molitoris J, Barclay K, Kolk M. When and where birth spacing matters for child survival: an international comparison using the DHS. Demography 2019;56:1349-70.

32 Baqui $\mathrm{AH}$, Ahmed S, El Arifeen S, et al. Effect of timing of first postnatal care home visit on neonatal mortality in Bangladesh: a observational cohort study. BMJ 2009;339:b2826.

33 Singh A, Yadav A, Singh A. Utilization of postnatal care for newborns and its association with neonatal mortality in India: an analytical appraisal. BMC Pregnancy Childbirth 2012;12:33.

34 Kikuchi K, Yasuoka J, Nanishi K, et al. Postnatal care could be the key to improving the continuum of care in maternal and child health in Ratanakiri, Cambodia. PLoS One 2018;13:e0198829.

35 Warren C, Daly P, Toure L, et al. Postnatal care. Opportunities for Africa" s Newborns Cape Town, South Africa: Partnership for Maternal. Newborn and Child Health 2006:79-90. 